\title{
Some remarks on the position of adverb phrases (mainly in Danish)
}

\author{
Henrik Jørgensen \\ Aarhus University
}

\begin{abstract}
This paper draws up some general questions concerning the adverbs as a part of speech and the question of their linear surface order. Drawing on Danish examples, the paper suggests that investigation into adverb phrases and the implications of their position rules might lead to new and unexpected results concerning syntax, learnability, and cognition.
\end{abstract}

\section{Introduction}

Somewhere between 'some years ago' and 'many years ago', Sten Vikner and I had finished a project on object positions seen from a formal and functional point of view. A follow-up seemed natural, and I suggested that we should go on with adverb phrase positions. Sten liked the idea, but no sponsor could be found. Therefore, the world is still waiting for a solution to the problems concerning the position of adverb phrases. As a small greeting to Sten's anniversary, a brief overview of these unsolved problems seems appropriate. In my paper, I am going to present the problems mainly with Danish examples. Danish has a fascinating and wide repertoire of different adverbs used in widely varying styles, so it is tempting to show the whole span of possibilities with these examples. ${ }^{1}$

1 This paper draws on material presented in two lectures, one at the annual convention of the Grammatics Network in Slagelse (oct. 2015), another at the memorial for Svend Østergaard in May 2018. I am grateful to the audiences at both places for comments and suggestions.

Ken Ramshøj Christensen, Henrik Jørgensen \& Johanna L. Wood (eds.). 2019.

The Sign of the V-Papers in Honour of Sten Vikner. Dept. of English, School of Communication \& Culture, Aarhus University, pp. 361-372, doi:10.7146/aul.348.103. (C) The author(s). 


\section{The paradoxes of adverbs}

In a project trying to span both formal and functional aspects of grammar, it is natural to start out with the content side and reach out from there for the formal aspects of grammar. The adverb phrases have adverbs as their central element, and hence, the semantic and pragmatic aspects of the adverbs are a relevant starting point.

As a part of speech, the adverbs contribute to the content side of speech in many complex ways. Their impact may be drawn up in two paradoxes:

I: The adverbs are always recognisable to the receivers of the text $t^{2}$ in both semantic and pragmatic respects, although their phonetic form regularly varies considerably.

II: The adverbs are normally built on simple monomorphemic relations between phonological and semantic form, even though their pragmatic content regularly implies quite complex pragmatic factors.

Concerning paradox I, some factual observations may be adduced to support it.

One is the fact that quite many adverbs in Danish may vary considerably in their phonetic realisation. Heegaard \& Mortensen (2014) observe that the adverb faktisk ('in fact') occurs both in monosyllabic and disyllabic versions, and Heegaard (2015) shows that egentlig ('in reality') similarly may be reduced from a full trisyllabic form to an almost monosyllabic version. Other parts-of-speech may not be reduced this way, e.g. nouns or proper names. The fact that the realized phonetic versions vary so much indicates that the meaning is recognized at the slightest cue, and consequently, that rather reduced cues may be sufficient to convey the meaning.

Another fact to support paradox I is that sometimes even unrecognisable phonetic material may be understood as having some kind of adverbial function. I suppose that native speakers will recognize the functional character of the item pente in the following quotes from a dialect transcription as a (adverbial) swearword, in spite of the fact that this is

2 I use the word 'text' to denote any kind of actual statement in any kind of communication, whether in written or in spoken form.

3 Glossings of the Danish adverbs is to be taken with great precaution since their meaning often is quite complex, cp. Paradox II. 
an almost unrecognisable version of a swearword, spelled pinedød in the standard language:

\section{(1) Danish (dialect)}

Men -"det vil jeg pent fandneme it ha"

But - "That will I <swearword1> <swearword2> not have"

-de så: han ålti:

- that said he always

'But - 'that I damn well cannot accept' - so he always said.'

(2) Danish (dialect)

"I skal pente tage det hele med" sagde han så.

"You shall <swearword> take it all with", said he then.

-Han så: ålti "pente".

- He said always " $<$ swearword $>$ ".

-"Få de kåste pente skjellenge" så: han.

- "Because it costs <swearword> shillings", said he.

"You must damn well pick it all up, he then said. -He always said

"damn well" -"because it does damn well cost money".'

(see https://dialekt.ku.dk/dialektkort/\#Gammel-Rye)

The meta-comments from the narrator shows that the specific swear word pente is not current to him, either; it is a verbal quote of a darkened phrase used to characterize the old man. Nevertheless, the function is completely transparent.

A final fact is that at least one particular group of adverbs, namely swearwords, are phonetic reductions of complex meta-phrase. This goes for the above-mentioned pinedød, which is a reduction of ved Vorherres pine og $d ø d$ ('by the suffering and death of our Lord'), but also for several others, like the ubiquitous $s g u$, a reduction of så sandt Gud hjoelpe mig ('so truly God help me'). The road from being a meta-sentence to being an adverb shows that the phonetic form as such may not be the most important clue to the complexity of the meaning.

Concerning the second paradox, normal Danish adverbs like $n u$ ('now'), da ('then', 'indeed'), jo ('yes', 'just', 'actually'), vel ('surely') etc. are obviously mono-morphemic and hence, constitute a semantic unity on the content side. At the same time, such adverbs are pragmatically rather complex. Consider e.g. the word jo ('yes', 'indeed'), described in detail by Hansen \& Heltoft (2011). While the meaning as such in all its uses seems 
consistent enough, the discussion around the pragmatic content shows that the word may be used in a broad spectrum of actual uses. Ditte Boeg Thomsen (2015: 142-3) quotes Davidsen-Nielsen for the general function as a label for "what may or should be seen as established knowledge" and continues to discuss the polyphony of the word. She goes on to discuss the question whether the appeal to already established knowledge is contained in the meaning. On one hand, jo may be understood as an order not to contradict the speaker (see Hansen \& Heltoft 2011: 1051); on the other, jo may also be understood as an instruction that there is no conflict between the understanding of the situation between the speaker and the hearer. As Thomsen (2015: 143) points out, there is a dilemma between these two interpretations; either common knowledge is central, but difficult to observe for the linguist, or common knowledge is not central, and the situations where jo refers to explicit knowledge are superimposed on a pragmatic structure. An adverb like jo thus contains references to speaker and hearer, to the context and maybe also to the previous discourse. Since these references are not explicit, the best way to describe them would seem to be to see them as pragmatically implied. Furthermore, the adverb conveys an illocutionary act, either at statements concerning identity of opinions between the speaker and the hearer, or an instruction that perseverance in a disagreement will not be accepted. Rather than choosing one of these understandings as the semantic core, it seems more reasonable to describe the semantic aspect as the minimal common ground between these understandings and then describe the pragmatic possibilities as superimposed.

This single example is hopefully sufficient to explain what the implications of paradox II are.

In her discussion of an empirical investigation of the use of adverbs among young Danish-speaking children, Thomsen (2015) points to yet another paradox concerning adverbs: On one hand, their meaning is rather complex, and their pragmatic possibilities quite wide-ranging, but at the same time, these words are present even in the speech production of little children, even in a usage that converges well with the grown-up usage (Thomsen 2015: 152). This paradox is sharpened by another observation, namely that adverbs are usually unfocused and appear in the middle of the sentence where they are more difficult to distinguish. Nevertheless, as her investigation into adverb forms among Danish-speaking children shows, they are acquired correctly and in sufficiently well-formed versions. 


\section{A formal semantic and syntactic framework for adverbial meanings}

In 1974, Ebbe Grunwald made an experiment with a generalized definition of adverb phrases as some kind of meta-statements, using a generative semantic framework. The inspiration for this came from authors like Bartsch (1972) and Vennemann (1973). In such a framework, adverb phrases were to be seen as meta-predicates on sentences. Let us take a sentence with an adverb phrase like this:

(3) Unfortunately, he doesn't come tomorrow

Under this approach it would be paraphrased like this:

(3')It is unfortunate that he doesn't come tomorrow.

This approach would call for a transformation rule that will turn a metapredicate into an adverb phrase and at the same time elide the main clause frame containing the meta-predicate and lift the former object clause to main clause status:

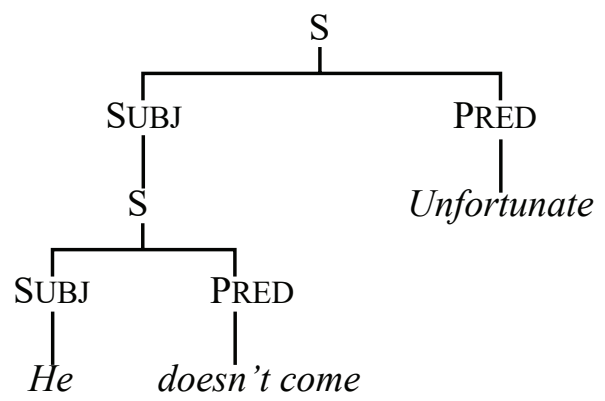

Generative grammar has since given up this kind of very complex transformations as theoretically inadequate. Also, from a purely descriptive approach, the solution does not work. In a response to this, Peter Harder (1975) pointed out that this solution cannot be generalized: 
(5) Indeed, he doesn't come

(5') *It is indeed that he doesn't come

The theory of adverb phrases as meta-predicates is a possible semantic (but not syntactic) explanation of certain structures, but definitely not all. For those that do not work well as predicates, Harder suggested that they should be seen as accompanying messages to the receiver on how to handle the core message.

Looking at the whole range of adverb types, Harder's approach seems to work well as a general definition. So, in a functional approach, what adverb phrases do is that they instruct the enunciatee how to handle the message. Using adverb phrases to convey such instructions may be paraphrased as meta-predicates, but this explanation only fits certain types. The approach analysing the adverbials as parts of the phatic communication has been carried further by polyphonic semantics.

But how could a formal approach handle Harder's suggestion? A more suitable approach seems to be to follow Cinque (1999) in his description of the adverbs as specifiers on functional nodes. If adverbs are seen as specifiers, they control the meaning of a given node at the A'-position. Specifier structures control and delimit the semantic scope of the whole construction, which is also what an intuitive approach to adverb phrases would expect them to do.

\section{Where to place adverb phrases?}

At a first glance, this question seems trite. Adverb phrases with superordinate semantic effects, like those built around evidential or performative adverbs, are placed in the middle of the sentence, while heavier types, like adverbs of place and time, and manner adverbs, are placed at the end of a sentence. This is equally true for English and Danish.

However, there are interesting twists in these matters. In Danish, clusters of adverbs are not infrequent, especially in colloquial style. Such clusters are always ordered quite strictly; few, if any deviations from a conventional order are acceptable. This conventional order was in fact first established inductively by Kristian Mikkelsen in 1911, simply from investigation into clusters in written standard Danish (see Jørgensen 2014: 100). Although this order cannot be identified fully with the general ordering rules in Cinque (1999), there is enough similarity to conclude that there must be a connection. This implies that Cinque's claim that some 
superordinate ordering rules of a universal nature are at play gains some inductive support from this observation.

But if such ordering rules are of a universal nature, it is tempting to assume that they are somehow also responsible for the acquisition of the adverbs and their meaning. This could explain why the adverbs are learnt anyway, in spite of their complexities in expression and meaning (cf. Thomsen 2015). If this is true, adverb phrase positions provide clues to some important aspects of the interface between language and cognition.

Another indication that such universal rules may be at play are the obvious grammaticalisations of adverbs in Danish. The development of sikker ('certain', 'sure') into an epistemic adverb (Jensen 2000) comes about because the effect of the adverb is different when moved from a position with a characterising function into a position with an epistemic function.

Danish sikkert has two meanings: 'presumably' (epistemic) and 'safely' (manner). If the position of the adverbial is doubtful, the epistemic meaning prevails:

(6) Han ankommer sikkert k1. 8. He arrives surely o'clock 8 'Presumably, he will arrive at 8 o'clock.'

When the adverb phrase is in final position, the manner reading prevails:

(7) Han er ankommet sikkert k1. 8 $\mathrm{He}$ is arrived surely o'clock 8 'He has arrived safely at 8 o'clock.'

If moved to the central position, the epistemic reading returns:

(8) Han er sikkert ankommet kl. 8 He is surely arrived o'clock 8 'He has presumably arrived at 8 o'clock.'

Such superordinate sequences of adverb phrases are evidently the basis for interesting observations concerning polysemous adverbs in Danish (see Jensen 2000).

Some linearisation rules of Danish adverbials are posed in Jørgensen (2014). The first model represents these rules as a box model where 
the adverb phrases of each type follow one another as boxes in a line (Diderichsen 1946; see also Bjerre et al. 2008 and Vikner \& Jørgensen 2017):

(9)

\begin{tabular}{|c|c|c|c|c|c|}
\hline \multicolumn{6}{|c|}{ adverbial zone } \\
\hline \multicolumn{4}{|c|}{ particles } & \multirow{2}{*}{$\begin{array}{l}\text { sentence } \\
\text { adverbs }\end{array}$} & \multirow[t]{2}{*}{ negations } \\
\hline phatic & proximal & $\begin{array}{c}\text { argumen- } \\
\text { tative }\end{array}$ & evidential & & \\
\hline
\end{tabular}

While the first four positions are narrowly defined by a close set of related semantic and pragmatic meaning effects caused by phonetic material in this position, the position named "sentence adverbs" is a mere cover term, which may be subdivided even further (Jørgensen 2014: 111). Since this discussion only deals with the general principles, there is no need to go into detail concerning this.

The model given above is in principle completely equivalent with a tree structure where all the functions of the particles are attached as specifiers to IP nodes in the same way as Cinque does.

Within the adverbial zone, there are some focus position, not bound by their content, but by their discourse function (Hansen \& Heltoft 2011: ch. IX \& XX; Jørgensen 2014):

\begin{tabular}{|c|c|c|c|c|c|c|c|}
\hline \multicolumn{8}{|c|}{ adverbial zone } \\
\hline \multicolumn{4}{|c|}{ particles } & sentence & SECONDARY & nega- & FOCUS \\
\hline phatic & $\begin{array}{c}\text { proxi- } \\
\text { mal }\end{array}$ & $\begin{array}{l}\text { argumen- } \\
\text { tative }\end{array}$ & $\begin{array}{l}\text { eviden- } \\
\text { tial }\end{array}$ & & & & \\
\hline
\end{tabular}

It seems as if there is also a possibility to focus adverbs by moving them to a position in front of the particles. The fact that there are particular focus positions that may be filled with material from other adverb phrase positions may look like an loophole to account for apparent counter-examples. 
While such a use would definitely be out of bounds, the possibility of focus positions seems undeniable, the focusing function making itself felt strongly in actual examples. Furthermore, the focusing function also seems to be a source of grammaticalisation in situations like the development of one single adverb into a pair of homonyms, like sikker discussed above.

In order to demonstrate which adverbs may occur in which orders, here is a repetition of the first model now filled with the relevant examples (see Jørgensen 2014: 103):

\begin{tabular}{|c|c|c|c|c|c|}
\hline \multicolumn{6}{|c|}{ adverbial zone } \\
\hline \multicolumn{4}{|c|}{ particles } & \multirow{2}{*}{$\begin{array}{l}\text { sentence } \\
\text { adverbs }\end{array}$} & \multirow[t]{2}{*}{ negations } \\
\hline phatic & proximal & $\begin{array}{l}\text { argumen- } \\
\text { tative }\end{array}$ & evidential & & \\
\hline $\begin{array}{l}\text { jo, mon, } \\
\text { vel, sgu }\end{array}$ & $n u, d a, s a ̊$ & $\begin{array}{l}\text { altså, ellers, } \\
\text { da, dog }\end{array}$ & $\begin{array}{c}\text { vel, vist, } \\
\text { nok, vistnok }\end{array}$ & & \\
\hline
\end{tabular}

\section{Linearisation at work.}

The rules stated above may be tested against empirical data. An excellent testbed were the weekly comments by the Danish author Bent Vinn Nielsen in the newspaper Information, regrettably discontinued since 2018 due to age. His style strongly leaned on oral patterns and often mocked the opinions of his opponents by confronting their speech habits with ironic twists. Due to this, he excelled in the use of adverbs and often delivered quite complex clusters.

In Jørgensen (2014), I investigated his linearisation of adverbs in clusters, using the patterns described above. It turned out that in almost all cases, the linear order followed the schemata for clusters set up in sect. 4 . Here are two examples:

(12) Men bevares, det er der jo indtil videre heller But by.all.means, that is there indeed until further neither ikke noget, der tyder på, at det gør. not anything that hints on that it does

'But anyhow, so far, nothing seems to suggest that it does.' 
(13) Jeg vil læne mig tilbage i yndlingslænestolen I will lean myself back in favourite-armchair-DEF derhjemme og nippe til min lille single malt og vedtage med at-home and sip at my little single malt and decide with migselv, at jeg jo nu engang ikke kan løse alle myself that I indeed now anyway not can solve all verdens problemer. world-DEF's problems 'I will lean back in my favourite armchair at home, sip at my little single malt and decide for myself that I can't solve all problems in this world.'

In both (12) and (13), we have some rather elaborate adverb clusters. Their linear order conforms in both cases with the models for the adverbial zone given in (9)-(11) above. Even though these adverb clusters are primarily used in oral, non-academic styles, there seems to be no single example that does not follow the rules of the linear order.

Such negative results may seem frustrating. The researcher works his/her way through a huge number of examples, and the conclusion is simply that there seem to be no interesting deviations; everything works completely in accordance with the theoretical model that was set up at the beginning. Nevertheless, their actual impact lies at another level. The negative conclusion actually points to the fact that there is a regularity in this matter. The adverbs do not appear in any random order, on the contrary. But the existence of such a regularity calls for new lines of thought: Why is this so? This is the relevance of the original proposal. And an important part of the challenge is that neither strictly formal approaches nor strictly functional ones will be able to find their way into the core of the problem. A formal approach may describe structures and regularities, but a functional approach may point to the forces behind the structures.

\section{Conclusion}

Many interesting questions concerning the adverb phrases and their meaning seem to hide in the question of linearisation. First of all, the linear order seems to be rather constant and rather universal, as also argued by Cinque. Whether this is due to any kind of top-down rationality (implicit in all attempts to explain linearisation through scope), or whether there is some less restrictive ordering principle behind it, is difficult to answer. 
Furthermore, such a question opens a Pandora's box of metaphysical problems. Nevertheless, a linguist may illuminate some of these problems in a completely sound and safe way by looking into the interface between the pragmatic effects. This is why it would have been interesting to work in detail with the linearisation of adverb phrases and also apply the results across different languages.

\section{References}

Bartsch, Renate. 1972. Adverbialsemantik. Frankfurt am Main: Athenäum Verlag. Bjerre, Tavs, Eva Engels, Henrik Jørgensen \& Sten Vikner. 2008. Points of convergence between functional and formal approaches to syntactic analysis. Working Papers in Scandinavian Syntax 82. 131-166.

Cinque, Guglielmo. 1999. Adverbs and Functional Heads. Oxford: Oxford University Press.

Diderichsen, Paul. 1946. Elementoer dansk grammatik. [Elementary Danish grammar.] Copenhagen: Gyldendal.

Grunwald, Ebbe. 1974. Aspekter af modale udsagns dybstruktur. [Aspects of the deep structure of modal sentences.] Nydanske studier \& Almen kommunikationsteori 7. 7-30. doi:10.7146/nys.v7i7.10350.

Hansen, Erik \& Lars Heltoft. 2011. Grammatik over det danske sprog. [Grammar of the Danish language]. Copenhagen: Det danske Sprog- og Litteraturselskab. Harder, Peter. 1975. Prædikatstruktur og kommunikativ funktion. [Predicate structure and communicative function.] Nydanske studier \& almen kommunikationsteori 8. 103-111. doi:10.7146/nys.v8i8.10359.

Heegard, Jan. 2015. Ordvarighed og grammatisk og pragmatisk funktion. Tilfældet egentlig. [Word duration and grammatical and pragmatic function. The case of egentlig.] Nydanske Sprogstudier 49. 61-97. doi:10.7146/nys.v1i49.22904.

Heegard, Jan \& Janus Mortensen. 2014. Fonetisk reduktion og kommunikative kontraster. Tilfældet faktisk. [Phonetic reduction and communicative contrasts. The case of faktisk.] Ny forskning i grammatik 21. 87-102.

Jensen, Eva Skafte. 2000. Sætningsadverbialer og topologi med udgangspunkt i de konnektive adverbialer. [Sentence adverbs and topology discussed on the basis of the connective adverbs.] Ny forskning i grammatik 7. 141-154.

Jørgensen, Henrik. 2014. Adverbiernes rækkefølge i henhold til Mikkelsen. [The sequence of adverbs according to Mikkelsen.] In Ole Togeby, Sten Vikner \& Henrik Jørgensen (eds.), Problemer og perspektiver i dansk syntaks [Problems and perpectives in Danish syntax.], 90-115. Odense: Syddansk Universitetsforlag. 
Mikkelsen, Kristian. 1911. Dansk ordföjningslcere. [Danish syntax.] Copenhagen: Lehmann \& Stage.

Thomsen, Ditte Boeg. 2015. Én stavelse, to synsvinkler. Børns tilegnelse af dialogiske partikler. [One syllable, two points of view. Children's acquisition of dialogic particles.] Nydanske Sprogstudier 48. 138-163. doi:10.7146/nys. v48i48.21138.

Vennemann, Theo. 1973. Explanations in Syntax. In John P. Kimball (ed.), Syntax and semantics. Volume 2, 1-50. New York: Seminar Press.

Vikner, Sten \& Henrik Jørgensen. 2017. En formel vs. En funktionel tilgang til dansk sætningsstruktur. [A formal vs. a functional approach to Danish syntactic structure.] Nydanske Sprogstudier 52-53. 135-168. doi:10.7146/nys.v1i5253.24954 . 